\title{
Cats undergoing spay with medetomidine, ketamine and butorphanol develop arterial oxygen desaturation independent of surgical positioning and increased intraocular pressure in Trendelenburg position
}

\author{
Corona, D ; Ranninger, Elisabeth ; Jörger, Fabiola Binia ; Goldinger, E ; Stefan, A ; Torgerson, Paul R ; \\ Bettschart-Wolfensberger, Regula
}

\begin{abstract}
This study observed the effects of three different surgical positions on arterial blood oxygenation measured noninvasively by pulse oximetry (SpO2) and on intraocular pressure (IOP) in anaesthetised cats undergoing spay. A total of 222 female feral cats were anaesthetised for a large-scale trap-neuter-return program with an intramuscular combination of medetomidine $(0.03-0.05 \mathrm{mg} / \mathrm{kg})$, ketamine $(7-10 \mathrm{mg} / \mathrm{kg})$ and butorphanol $(0.4$ $\mathrm{mg} / \mathrm{kg})$. Cats were randomly allocated to undergo spay in either Trendelenburg $\left(70^{\circ}\right.$ downward head tilt), lateral or dorsal recumbency. SpO2 and pulse rate were measured at baseline, prior to surgical positioning, after one minute in surgical position and in one-minute intervals after surgical incision. Intraocular pressure was measured before positioning and at the end of surgery. At the end of surgery, all cats were placed into left lateral recumbency and all parameters were revaluated after five minutes. No significant differences between the three positions were found regarding SpO2, but an increase over time was observed. In total, $52 \pm 10 \%$ (mean $\pm \mathrm{SD})$ of cats were hypoxaemic $(\mathrm{SpO} 2<90 \%)$ at baseline. SpO2 improved over time, but $27 \pm 3 \%$ (mean $\pm \mathrm{SD})$ of the cats remained hypoxaemic at the end of surgery. Trendelenburg position increased IOP during surgery (mean $31 \pm 6 \mathrm{mmHg}$, individual max. $48 \mathrm{mmHg}$, versus $17 \pm 4 \mathrm{mmHg}$ in dorsal/lateral recumbency) but normalised after 5 mins in lateral recumbence. All cats recovered well from surgery and were released within 24 hours post-anaesthesia. Surgical position was shown to have no notable influence on SpO2 during anaesthesia in cats not receiving oxygen supplementation, whereas Trendelenburg position led to increased IOP. Oxygen supplementation is recommended with this anaesthetic protocol, as hypoxaemia is frequently observed.
\end{abstract}

DOI: https://doi.org/10.17236/sat00271

Other titles: Kastration von Katzen mit Medetomidin, Ketamin und Butorphanol führen unabhängig von der chirurgischen Positionierung zur arteriellen Hypoxaemie und in der Trendelenburg-Position zu einem erhöhten Augen innendruck

Posted at the Zurich Open Repository and Archive, University of Zurich ZORA URL: https://doi.org/10.5167/uzh-190380

Journal Article

Published Version

Originally published at:

Corona, D; Ranninger, Elisabeth; Jörger, Fabiola Binia; Goldinger, E; Stefan, A; Torgerson, Paul R; BettschartWolfensberger, Regula (2020). Cats undergoing spay with medetomidine, ketamine and butorphanol develop arterial oxygen desaturation independent of surgical positioning and increased intraocular pressure in Trendelenburg position. Schweizer Archiv für Tierheilkunde, 162(9):539-550.

DOI: https://doi.org/10.17236/sat00271 


\title{
Cats undergoing spay with medetomi- dine, ketamine and butorphanol develop arterial oxygen desaturation independ- ent of surgical positioning and increased intraocular pressure in Trendelenburg position
}

\author{
D. Corona', E. Ranninger1, F. B. Jörger'1, E. Goldinger2,3, A. Stefan', \\ P. Torgerson ${ }^{5}$, R. Bettschart-Wolfensberger ${ }^{1}$
}

1 Department of Clinical Diagnostics and Services, Section of Anaesthesiology, Vetsuisse Faculty University of Zurich, Switzerland; ${ }^{2}$ Tezet Tiermedizinisches Zentrum AG, Müllheim, Switzerland; ${ }^{3}$ NetAP Network for Animal Protection, Switzerland; ${ }^{4}$ Center of Hope Veterinary Hospital, Pitesca, Ilfov, Romania; ${ }^{5}$ Section of Epidemiology, Vetsuisse Faculty University of Zurich, Switzerland

\begin{abstract}
This study observed the effects of three different surgical positions on arterial blood oxygenation measured noninvasively by pulse oximetry $\left(\mathrm{SpO}_{2}\right)$ and on intraocular pressure (IOP) in anaesthetised cats undergoing spay.

A total of 222 female feral cats were anaesthetised for a large-scale trap-neuter-return program with an intramuscular combination of medetomidine $(0.03-0.05 \mathrm{mg} /$ $\mathrm{kg})$, ketamine $(7-10 \mathrm{mg} / \mathrm{kg}$ ) and butorphanol $(0.4 \mathrm{mg} /$ $\mathrm{kg})$. Cats were randomly allocated to undergo spay in either Trendelenburg $\left(70^{\circ}\right.$ downward head tilt $)$, lateral or dorsal recumbency. $\mathrm{SpO}_{2}$ and pulse rate were measured at baseline, prior to surgical positioning, after one minute in surgical position and in one-minute intervals after surgical incision. Intraocular pressure was measured before positioning and at the end of surgery. At the end of surgery, all cats were placed into left lateral recumbency and all parameters were revaluated after five minutes. No significant differences between the three positions were found regarding $\mathrm{SpO}_{2}$, but an increase over time was observed. In total, $52 \pm 10 \%$ (mean \pm SD) of cats were hypoxaemic $\left(\mathrm{SpO}_{2}<90 \%\right)$ at baseline. $\mathrm{SpO}_{2}$ improved over time, but $27 \pm 3 \%$ (mean \pm SD) of the cats remained hypoxaemic at the end of surgery. Trendelenburg position increased IOP during surgery (mean $31 \pm 6 \mathrm{mmHg}$, individual max. $48 \mathrm{mmHg}$, versus $17 \pm$ $4 \mathrm{mmHg}$ in dorsal/lateral recumbency) but normalised after 5 mins in lateral recumbence. All cats recovered well from surgery and were released within 24 hours post-anaesthesia.
\end{abstract}

Kastration von Katzen mit Medetomidin, Ketamin und Butorphanol führen unabhängig von der chirurgischen Positionierung zur arteriellen Hypoxaemie und in der TrendelenburgPosition zu einem erhöhten Augen innendruck

In dieser Studie wurden die Auswirkungen von drei verschiedene Positionen während der Kastration auf die arterielle Sauerstoffsättigung $\left(\mathrm{SpO}_{2}\right)$ und den Augeninnendruck (IOD) untersucht.

Insgesamt wurden 222 Kätzinnen mit einer intramuskulären Kombination aus Medetomidin (0,03 - 0,05 mg/ $\mathrm{kg})$, Ketamin (7 - $10 \mathrm{mg} / \mathrm{kg}$ ) und Butorphanol (0,4 mg/ $\mathrm{kg}$ ) für ein Fang-, Kastrations- und WiederfreilassungsProgramm anästhesiert. Die Katzen wurden nach dem Zufallsprinzip ausgewählt, um entweder in der Trendelenburg Position (70 Abwärtsneigung des Kopfes), in Seitenlage (lateral) oder in Rückenlage (dorsal) kastriert zu werden. $\mathrm{SpO}_{2}$ und Pulsfrequenz wurden zu Beginn vor der chirurgischen Positionierung, nach einer Minute in der chirurgischen Position und in Intervallen von einer Minute nach der chirurgischen Inzision gemessen. Der IOD wurde vor der Positionierung und am Ende des chirurgischen Eingriffes gemessen. Nach der Kastration wurden alle Katzen in linke Seitenlage gebracht und alle Parameter nach fünf Minuten erneut gemessen. Für $\mathrm{SpO}_{2}$ konnte kein signifikanter Unterschied zwischen den drei Positionen gemessen werden, doch konnte ein Anstieg im Laufe der Zeit beobachtet werden. $\mathrm{Zu}$ https://doi.org/ $10.17236 /$ sat00271

Received: 20.06.2020 Accepted: 21.07.2020 
Cats undergoing spay with medetomidine, ketamine and butorphanol develop arterial oxygen desaturation independent of surgical positioning and increased intraocular pressure in Trendelenburg position

D. Corona et al.
Surgical position was shown to have no notable influence on $\mathrm{SpO}_{2}$ during anaesthesia in cats not receiving oxygen supplementation, whereas Trendelenburg position led to increased IOP. Oxygen supplementation is recommended with this anaesthetic protocol, as hypox-

Key words: feline, feral cats, haemoglobin oxygen desaturation, hypoxaemia, neutering aemia is frequently observed.

Studienbeginn wurde bei $52 \pm 10 \%$ (Mittelwert \pm SD) der Katzen eine Hypoxämie $\left(\mathrm{SpO}_{2}<90 \%\right)$ festgestellt, die sich im Laufe der Zeit verbesserte. Am Ende des Eingriffes wurde bei $27 \pm 3 \%$ (Mittelwert \pm SD) der Katzen im noch eine Hypoxämie festgestellt. Die Trendelenburg-Position erhöhte den IOD während der Kastration (Mittelwert $31 \pm 6 \mathrm{mmHg}$, individuell max. $48 \mathrm{mmHg}$ ) gegenüber $17 \pm 4 \mathrm{mmHg}$ in dorsaler oder lateraler Lage. Der IOD normalisierte sich jedoch nach 5 Minuten in linker Seitenlage. Alle Katzen erholten sich gut von der Kastration und konnten innerhalb von 24 Stunden nach der Anästhesie freigelassen werden.

Die Studie zeigte, dass die chirurgische Positionierung bei der Kastration ohne zusätzliche Sauerstoffergänzung keinen nennenswerten Einfluss auf die $\mathrm{SpO}_{2}$ hat. Die Trendelenburg-Positionierung führt jedoch zu einem erhöhten Augeninnendruck. Aufgrund der beobachteten Hypoxämie wird eine Sauerstoffergänzung bei der Kastration mit dem vorliegenden Anästhesieprotokoll empfohlen.

Schlüsselwörter: Streunende Katzen, Sauerstoffsättigung, Hämoglobin, Hypoxämie, Kastration

\section{Introduction}

Globally, the population of feral cats is estimated at 100 million, which includes unowned and undomesticated cats. ${ }^{20}$ Concern about the impact of free-roaming cats on the environment and public health, as well as considerations concerning animal welfare and ethics, has led to various efforts to control their numbers. While the trap-neuter-return (TNR) program is considered the most practical, effective and humane way to control feral cat populations ${ }^{13}$ any surgical intervention in cats necessitates anaesthesia. When compared to a clinical hospital setting, general anaesthesia in field conditions is associated with increased morbidity and mortality. $^{2}$

One possible factor that might influence morbidity is the surgical technique and positioning of the animal during surgery. Particularly, the Trendelenburg position is potentially associated with complications ${ }^{6}$ since the weight of the abdominal viscera can impair normal diaphragmatic movements and reduce functional residual capacity (FRC) and increase atelectasis formation. In humans, the Trendelenburg position has been associated with more pronounced effects on the pulmonary and cardiovascular system when compared to the supine position. ${ }^{6}$ Other complications associated with this particular positioning are regurgitation as well as raised intracranial (ICP) and intraocular pressure (IOP). ${ }^{4}$ The extent of the tilt can influence the severity and the likelihood of arising complications. Thereby, positioning during surgery may have an influence on cardiopulmonary function and therefore also on anaesthesia risk.

The Trendelenburg position was initially described as a $15^{\circ}-45^{\circ}$ head-down tilt by a pioneering German surgeon, Friedrich Trendelenburg, in the mid $19^{\text {th }}$ century. In Switzerland, Austria and Germany, spaying of female cats is performed often in the Trendelenburg position (about $70^{\circ}$ downward head tilt), a surgical position which has gained popularity given that it allows the surgeons to have easier access to the ovaries, shortening

To obtain reliable anaesthesia to neuter feral cats, a combination of different intramuscular drugs is typically used.9,12,23,29 Medetomidine-ketamine-butorphanol is a well-established combination widely used for injectable anaesthesia in cats given that it provides analgesia, the volume to be injected is relatively low and in case of complications, at least part of the combination is reversible. Since opioids and ketamine provide analgesia but limited muscle relaxation, ${ }^{23}$ the addition of an alpha- 2 adrenergic agonist like medetomidine typically results in improved quality of anaesthesia and analgesia for short elective surgical procedures. ${ }^{12,29}$

In veterinary practice, particularly under field conditions, it is relatively common to perform anaesthesia for minor surgery without oxygen supplementation and no support of respiration or cardiopulmonary function, ${ }^{9}$ even though it is well known that hypoxaemia resulting overall surgical time. ${ }^{3}$ 
in hypoxia under general anaesthesia is one of the most common anaesthesia-related risk factors increasing mortality in cats. ${ }^{5}$

The purpose of this study was to evaluate the effects of three different surgical positions on haemoglobin oxygen saturation $\left(\mathrm{SpO}_{2}\right)$, pulse rate (PR) and IOP in anaesthetised cats undergoing spay in $70^{\circ}$ downward head tilt, dorsal or lateral recumbency.

\section{Materials and Methods}

\section{Study design}

This prospective, observational, non-experimental study was performed during a trap neuter return programme in feral cats in Romania financed by Network for Animal Protection (NetAP) Switzerland. All observations concerning the study were non-invasive and performed in the anaesthetised patients only. Animals were captured and handled with care according to the standards of the Center of Hope Veterinary Hospital Pitesca, Ilfov, Romania. All procedures were performed by experienced professionals according to the standards of NetAP Switzerland.

\section{Animals}

A total of 339 feral male and female cats were admitted to a large-scale TNR program in Romania in collaboration with the NetAP-Switzerland and Romania Animal Rescue (RAR). Cats were captured from local colonies using commercially available traps and were referred to a local veterinary hospital in the late afternoon or early evening before surgery. There cats were carefully observed from the distance for major pathologies and health concerns, fed a commercial diet and weighed.

Following an acclimatisation period of two hours, neurologic function gait inside the cage, pupillary reflexes, level of consciousness and eating behaviour were assessed and videotaped from outside the cage in order to judge their preoperative behaviour. Any signs of abnormal neurologic function were noted. Food was withheld for 10 - 16 hours prior to anaesthesia, whereas free access to water was provided. As routine physical examination was not possible based on visual examination from a distance, only apparently healthy female cats were included.

\section{Anaesthesia and surgery}

A total of 244 female cats of unknown age were enrolled. There were always three different very experienced surgeons, each one familiar with one surgical technique, working in parallel. The cats were randomly allocated to one of these surgeons and like this also to one of the three recumbency groups, $70^{\circ}$ downward head tilt group
(HG, cat neutered with hanging technique) (Figure 1), dorsal group (DG, cat neutered in dorsal recumbency) and flank group (FG, cat neutered in right lateral recumbency).

Anaesthesia was induced with a standard TNR protocol (https://www.netap.ch/de/) consisting of an intramuscular (i.m.) injection of medetomidine $(0.03-0.05 \mathrm{mg}$ / $\mathrm{kg}$ ) [Medetor $1 \mathrm{mg} / \mathrm{ml}$ ad us. vet.; D-Burgdorf-Virbac AG, Europastrasse 15, 8152 Opfikon, Switzerland], ketamine $(7-10 \mathrm{mg} / \mathrm{kg}$ ) [Narkamon $100 \mathrm{mg} / \mathrm{ml}$; Bioveta a.s, Komenského 212/12, 68323 Ivanovice na Hané, Czech Republic] and butorphanol $(0.4 \mathrm{mg} / \mathrm{kg})$ [Butomidor $10 \mathrm{mg} / \mathrm{ml}$; Richter Pharma AG, A4600 Wels, Austria], depending on the bodyweight of the cats. The medetomidine-ketamine-butorphanol (MKB) mixture was consistently injected into the supraspinatus muscle. If the first injection of MKB did not cause recumbency or reliable anaesthesia (withdrawal reaction to touch, vocalisation) within $10 \mathrm{~min}$, an additional dose of ketamine $(5 \mathrm{mg} / \mathrm{kg})$ was injected i.m. Once cats were in lateral recumbency and unresponsive to touch nor vocalising, the bladder was emptied manually and tolfedine $(4 \mathrm{mg} / \mathrm{kg})$ [Tolfedine; Vetoquinol AG Freiburgstrasse 255, 3018 Bern, Switzerland] and amoxicillin (15 mg/ kg) [Amoxycen 200Long Acting $200 \mathrm{mg} / \mathrm{ml}$; SC Biotur Exim SRL, soseana Turum Magurele km 5 Judetul Teleorman, Alexandria 140003, Romania] were administered subcutaneously (s.c.). The surgical area was clipped (either abdomen or flank) and the cats were moved to
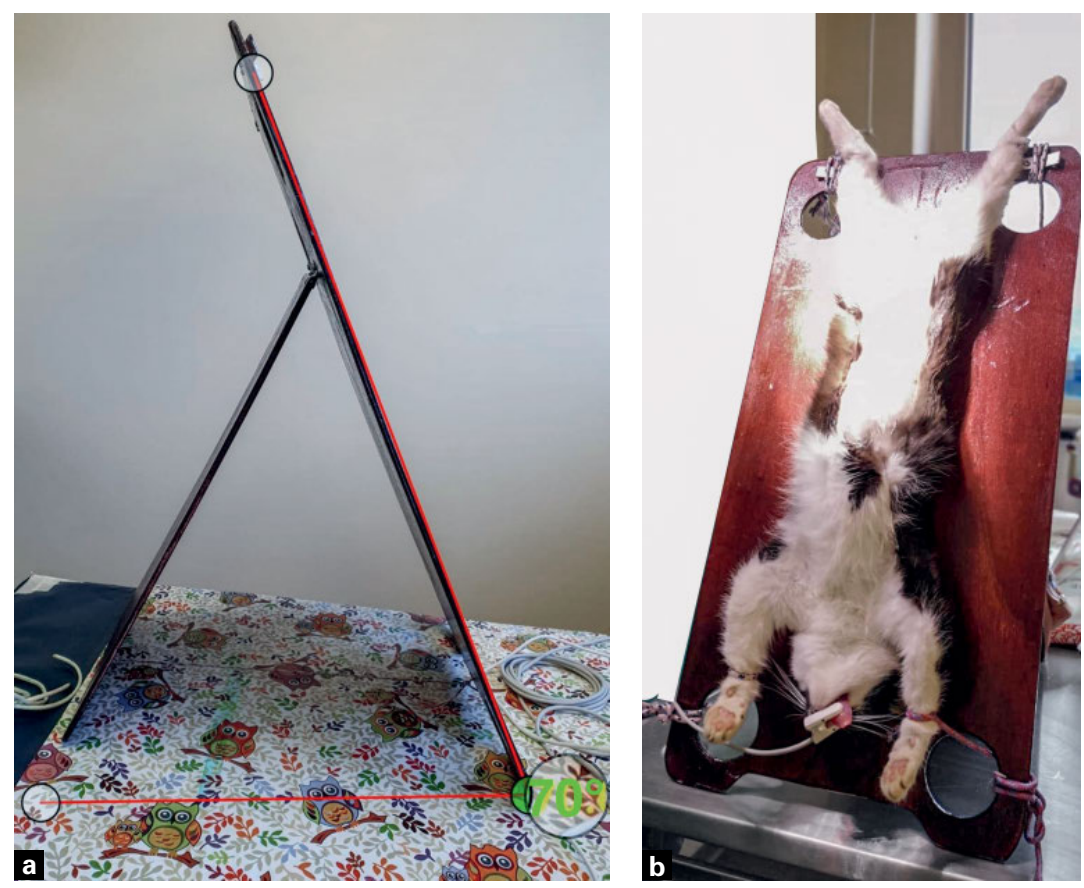

Figure 1: Veterinary surgical table for the Trendelenburg position was positioned in a $70^{\circ}$ angle (a). A feral cat in Tendelburg position for castration in $70^{\circ}$ downward head tilt (b), which allows the surgeons to have easier access to the ovaries and reducing overall surgical time.
Cats undergoing spay with medetomidine, ketamine and butorphanol develop arterial oxygen desaturation independent of surgical positioning and increased intraocular pressure in Trendelenburg position

D. Corona et al. 
Cats undergoing spay with medetomidine, ketamine and butorphanol develop arterial oxygen desaturation independent of surgical positioning and increased intraocular pressure in Trendelenburg position

D. Corona et al. the surgery room where they were placed in lateral recumbency. If patients were reacting, moving or vocalising during surgery, ketamine $(0.1 \mathrm{ml}=10 \mathrm{mg}$ i.m. $)$ was administered. In the recovery area animals received praziquantel $(5.7 \mathrm{mg} / \mathrm{kg})$ [Prazicest $56.8 \mathrm{mg} / \mathrm{ml}$; FarmaVet S.C. Pasteur Filiala Filipesti S.R.L. Str. Principala nr 944, Filipestii de Padura, Jud. Prahova, Romania] and ivermectin $(1 \mathrm{mg} / \mathrm{kg}$ ) [Biomec $10 \mathrm{mg} / \mathrm{ml}$; Bioveta a.s.,Komenského 212/12, 68323 Ivanovice na Hané, Czech Republic] s.c.

Eight, 12 and 24 hours after the end of anaesthesia all cats were observed for abnormal neurological behaviour or delayed pupillary reflexes. When no abnormalities were observed, the cats were returned to their original geographic location.

\section{Monitoring}

After one minute in lateral position (T0), the first measurements $\left(\mathrm{SpO}_{2}, \mathrm{PR}, \mathrm{IOP}\right)$ were taken. $\mathrm{SpO}_{2}$ and $\mathrm{PR}$ were measured with a Rad-67 Pulse Co-Oximeter [Masimo International Sarl, Puits Godet 10, 2000 Neuchâtel, Switzerland] and IOP with a rebound tonometer [TonoVet Tonometer Eickemeyer Medizintechnik für Tierärzte AG Sandgrube 29, 9050 Appenzell, Switzerland] according to the manufacturer's manual and temperature with a rectal thermometer. Intraocular pressure was measured bilaterally in all cats and measurements were taken without previous topical anaesthesia or eye ointment. Following the last IOP measurement, the eyes were protected with vitamin A eye ointment [Vitamin A Bausch \& Lomb Swiss AG, Industriestrasse 15A, 6301 Zug, Switzerland]. Following baseline measurements,

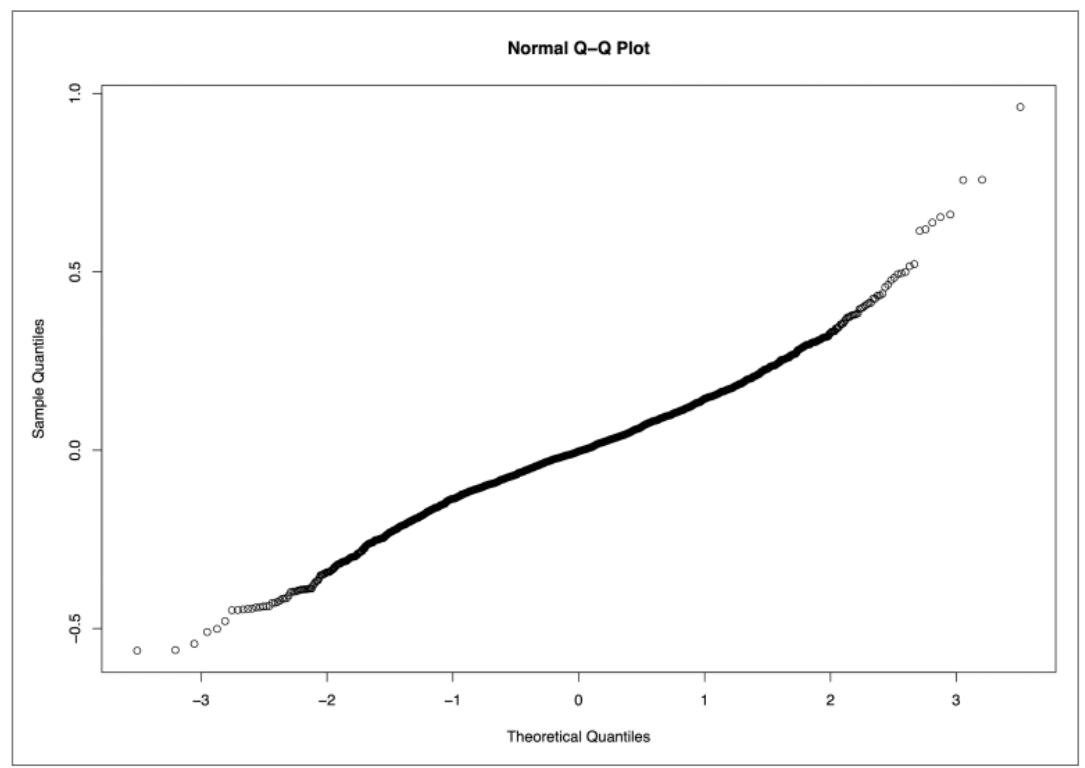

Figure 2: Residuals were checked for normal distribution using a Quantile - Quantile plot (Q-Q plot). Data points were closely following a straight line at a $45 \%$ angle upwards, suggesting a good model fit with normal distributed data. including IOP, animals were aseptically prepared and placed in position for surgery. After one minute in surgical position, $\mathrm{SpO}_{2}$, PR were measured and then surgery initiated. All surgeries were performed by the same surgeons experienced with the relevant surgical method. During surgery, $\mathrm{SpO}_{2}$ and $\mathrm{PR}$ were recorded every minute. At the end of surgery, before moving the cats from the surgery position to lateral recumbency, all parameters were measured again ( $\mathrm{SpO}_{2}, \mathrm{PR}, \mathrm{IOP}$, temperature). Thereafter, cats were placed in lateral recumbency for recovery from anaesthesia and $\mathrm{SpO}_{2}, \mathrm{PR}$, and IOP were revaluated after $5 \mathrm{~min}$ in lateral recumbency.

Duration of surgery was recorded for each group, as well as, time from the first i.m. injection to start of surgery. All data during surgery were recorded by three anaesthetists (DC, ER, FBJ), each of whom rotated daily to record data of a different group.

\section{Statistical analysis}

All data were analysed in R. ${ }^{28}$ Data were analysed by a generalised additive mixed model (GAMM) using the $\mathrm{R}$ package gamma4 (Version: 0.2-5). ${ }^{31}$ Thus any variation in $\mathrm{SpO}_{2}$, PR and IOP between the different positions used and possible linear and non-linear variation over time were analysed whilst controlling for repeated measures within each cat. Data are reported as mean \pm SD. Various models were compared and the model that gave the lowest Akaike information criterion (AIC) was chosen. Residuals were checked using a Quantile Quantile plot (Q-Q plot) (Figure 2).

One way ANOVA corrected for repeated measures (Graph-pad Version: 8.4.2) was used to analyse time from MKB injection to start of surgery and for surgery time.

\section{Results}

Our data were not normally distributed and the best fitting model was a GAMM model with a Gamma distribution link function. The distribution of residuals suggested this was a good model fit (Figure 2).

\section{Animals, time intervals and surgical duration}

A total of 244 female feral cats were anaesthetised with $\mathrm{MKB}$ and were randomly allocated into three groups, with 82 cats in the HG, 76 cats in the DG and 86 cats in the FG. Twenty-two cats were excluded during surgery (3 from HG, 7 from DG and 12 from FG) due to intraoperative complications (bleeding, diaphragmatic hernia, advanced gestation). As such, 222 female cats were evaluated for the data analysis and survived the procedure to discharge. Body weights of the cats enrolled in 
the study ranged from 1.0 to $4.3 \mathrm{~kg}(3 \pm 0.55 \mathrm{~kg})$. There was no significant difference between the groups regarding body weight.

Signs of regurgitation, such as gastric contents coming out of the mouth or nostrils, were not evident in any cat.

The times after first MKB injection to start of surgery were not significantly different between the three groups, $17 \pm 6 \mathrm{~min}$ in HG, $15.2 \pm 6.2 \mathrm{~min}$ in FG and $16.5 \pm 7.3 \mathrm{~min}$ in DG $(\mathrm{p}=0.2025)$. Significant difference was found for the surgery times, $8 \pm 2.4 \mathrm{~min}$ in HG, $8 \pm 3 \mathrm{~min}$ in FG and $10.6 \pm 3.8 \mathrm{~min}$ in DG respectively $(\mathrm{p}<0.0001)$. Average time of head down position was $9 \pm 2.4 \mathrm{~min}$.

\section{Need for additional anaesthesia}

Forty-four cats required a second i.m. injection of ketamine after the first injection of $\mathrm{MKB}$, which included nine cats in the HG, 17 in the FG (5 of which were excluded) and 18 in the DG (4 of which were excluded). Fifteen cats required i.m. ketamine before starting surgery due to a light plane of anaesthesia (6 in HG - 3 in FG -6 in DG) and 29 cats intraoperatively because reacting to the surgical stimulus ( 3 in HG - 14 in FG - 12 in DG). Total additional ketamine dose range was $6 \pm$ $1 \mathrm{mg} / \mathrm{kg}$ in each group. The overall ketamine dose used in total was $11 \mathrm{mg} / \mathrm{kg}$ i.m. ( $\mathrm{HG}=10.6 \mathrm{mg} / \mathrm{kg}, \mathrm{FG}=11.24$ $\mathrm{mg} / \mathrm{kg}, \mathrm{DG}=11.3 \mathrm{mg} / \mathrm{kg}$ ). In summary, $18 \%$ of all enrolled female cats $(44 / 244)$ and $15.7 \%$ of the included female cats in the study (35/222) needed supplemental ketamine.

\section{Monitored parameters during anaesthesia} Overall, the PR ranged between $60-263$ beats $/ \mathrm{min}$, in HG (60 - 230 beats/min), in FG (60 - 240 beats/min) and in DG (61 - 263 beats/min) (Figure 3).

Statistical analysis revealed a non-linear relationship over time in all groups, with an increase of PR during the first 5 minutes followed by a decrease $(\mathrm{p}<0.001)$ (Figure 4).

At T0 (upon arrival to surgical theatre, one minute before positioning for surgery) haemoglobin oxygen desaturation $\left(\mathrm{SpO}_{2}<90 \%\right)$ was observed in all groups, $64 \%$ in $\mathrm{HG}, 43 \%$ in FG, $49 \%$ in DG. Mean $\mathrm{SpO}_{2}$ for each group was $85 \pm 9.3 \%$ in $\mathrm{HG}, 87 \pm 7.3 \%$ in $\mathrm{FG}, 87 \pm 8.1 \%$ in DG. While $\mathrm{SpO}_{2}$ values improved over time (Figure 5 and 6), at the end of surgery and before moving the animals from their respective recumbency, overall $34 \pm$ $5 \%$ showed $\mathrm{SpO}_{2}<90 \%$ (34\% in HG, 30\% in FG, $40 \%$ in DG). After $5 \mathrm{~min}$ in lateral recumbency from the end of surgery, the overall incidence of $\mathrm{SpO}_{2}<90 \%$ was 27 $\pm 3 \%(30 \%$ in $\mathrm{HG}, 24 \%$ in $\mathrm{FG}, 27 \%$ in $\mathrm{DG})$.

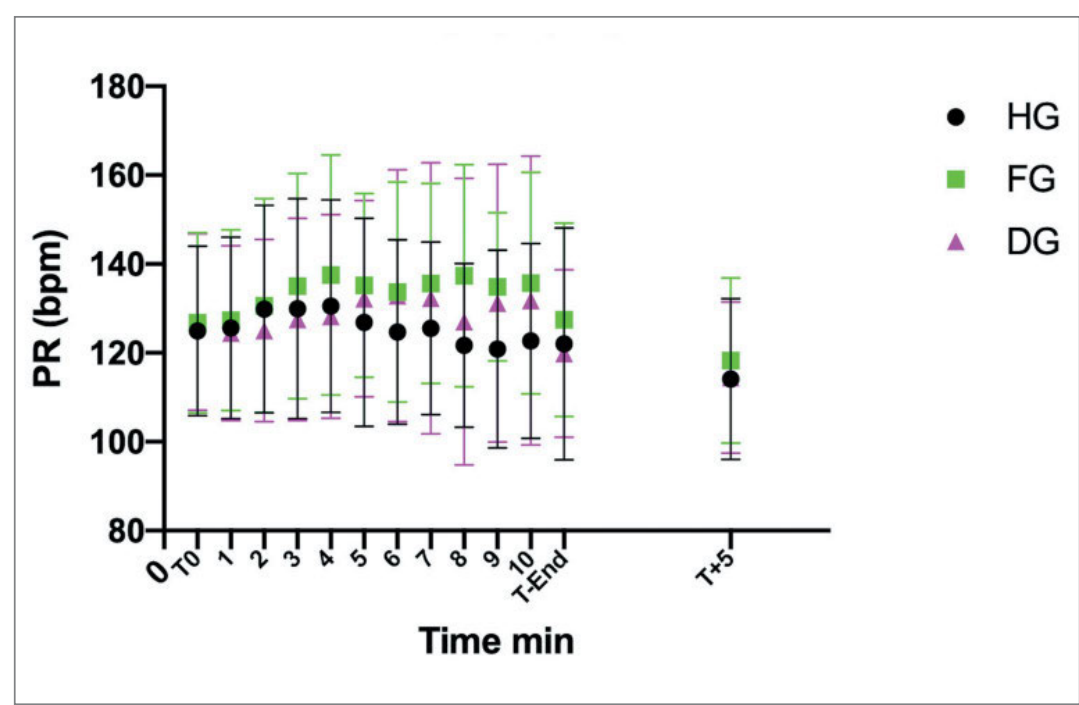

Figure 3: Pulse rates (mean \pm SD) from 222 cats undergoing neutering in different body positions [HG (Head down/Trendelenburg Group) = 79, FG (Flank Group) = 74, DG (Dorsal Group) $=69$.

T0 $=1$ Minute before positioning for surgery; 1-10 = 10 min during surgery; T-End = End of surgery; $\mathbf{T}+\mathbf{5}=5 \mathrm{~min}$ in lateral recumbency after end of the procedure

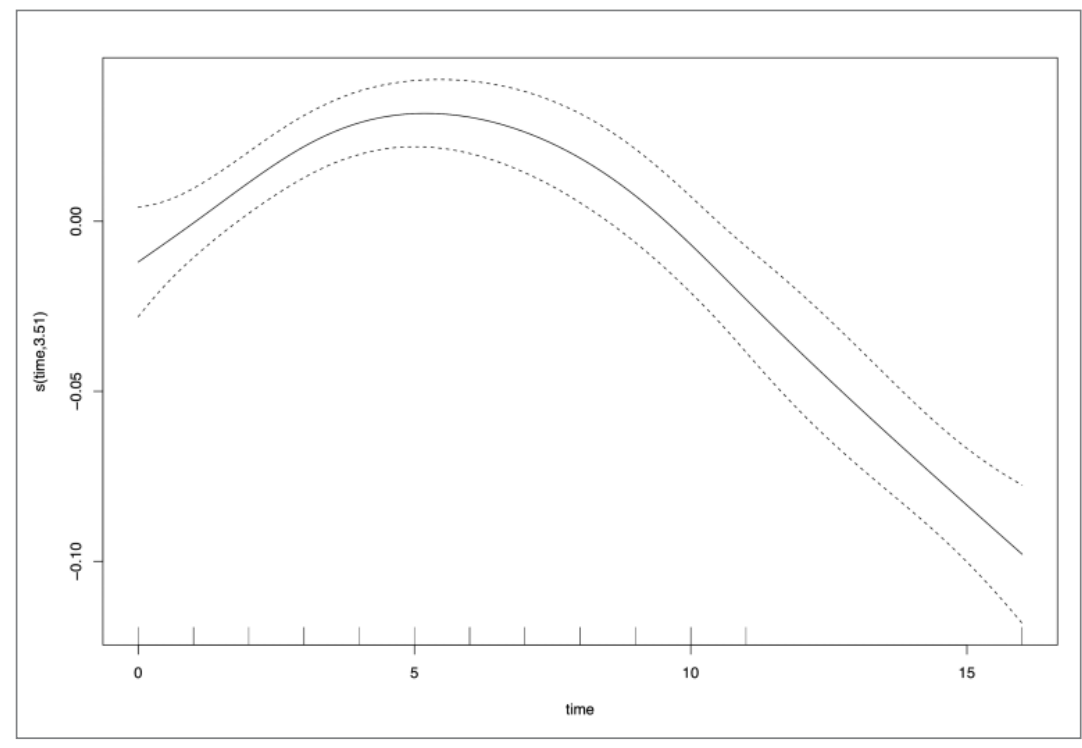

Figure 4: Estimate change (solid line) and $95 \% \mathrm{Cl}$ (dashed line) by a generalised additive mixed model (GAMM) analysis for pulse rate (PR) from 222 cats undergoing neutering in different body positions [HG (Head down/Trendelenburg Group) = 79, FG (Flank Group) = 74, DG (Dorsal Group) =69].

There was no significant evidence that positioning of the cat had any effect on $\mathrm{SpO}_{2}$. Nevertheless, a non-linear increase with time was found ( $p<0.001)$, with the increase occurring during the first 6 minutes before reaching a plateau (Figure 5).

The average IOP at baseline was $18 \pm 4 \mathrm{mmHg}$ for all groups. In the DG and FG groups, IOP values remained unchanged at $17 \pm 4 \mathrm{mmHg}$ throughout the surgery. In contrast, IOP significantly increased to $31 \pm 6 \mathrm{mmHg}$ in the $\mathrm{HG}$ with a maximal recorded value of $48 \mathrm{mmHg}$. 


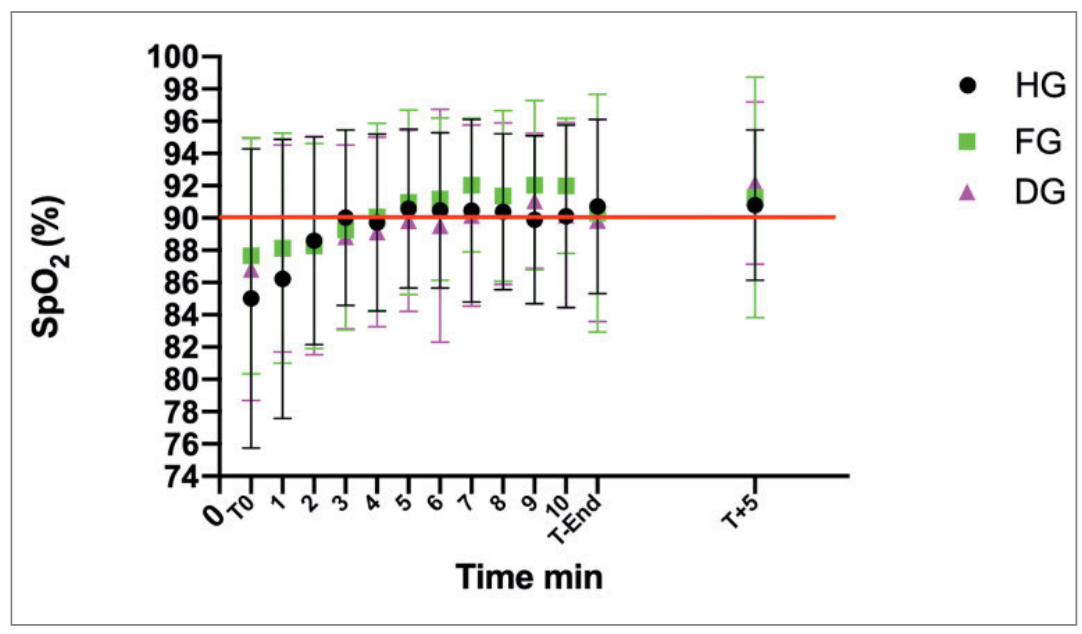

Figure 5: $\mathrm{SpO}_{2}$ trend over time for each group [HG (Head down/Trendelenburg Group) = 79, FG (Flank Group) = 74, DG (Dorsal Group) $=69]$.

T0 = 1 Minute before positioning for surgery; 1-10 = 10 min during surgery; $\mathbf{T}$-End = End of surgery; $\mathbf{T + 5}=5 \mathrm{~min}$ in lateral recumbency after end of the procedure.

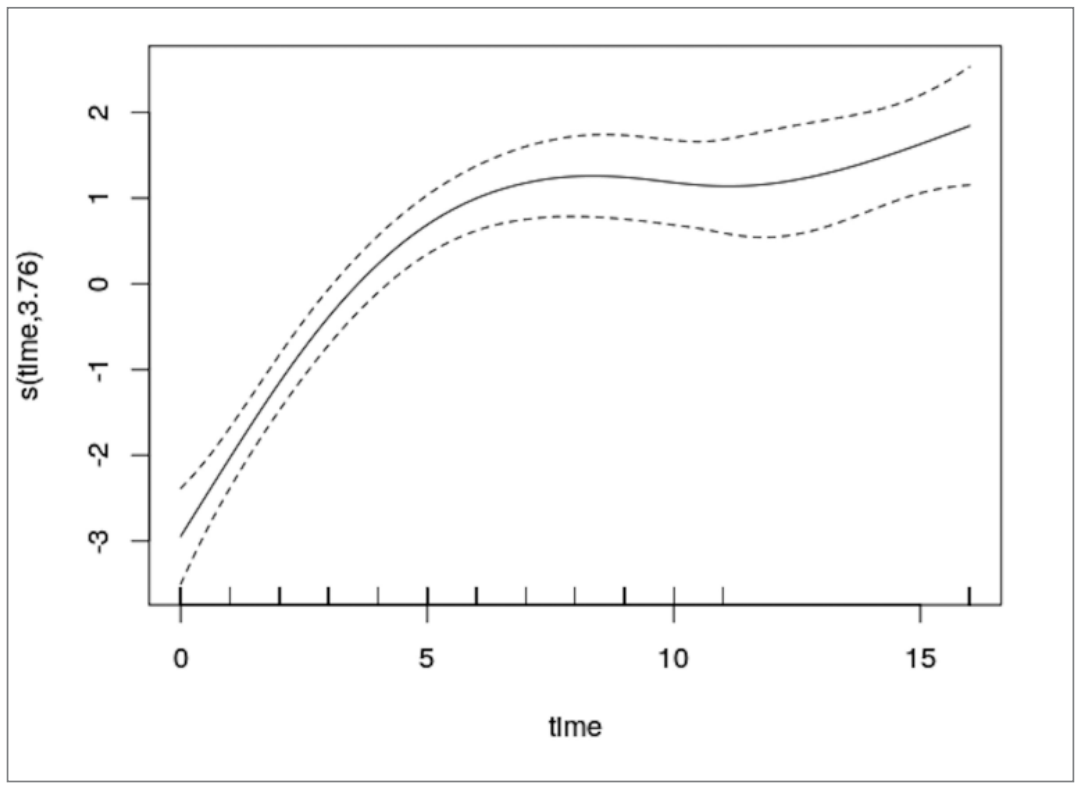

Figure 6: Estimate change (solid line) and $95 \% \mathrm{Cl}$ (dashed line) by a GAMM analysis for arterial blood oxygenation $\left(\mathrm{SpO}_{2}\right)$ from 222 cats undergoing neutering in different body positions [HG (Head down/Trendelenburg Group) = 79, FG (Flank Group) =74, DG (Dorsal Group) $=69]$.

\section{Discussion}

The incidence of severe hypoxaemia in the present study was very high, with over $50 \%$ of the cats having $\mathrm{SpO}_{2}$ levels below $90 \%$ before and during spaying. In cats, hypoxia has been previously described when combinations of medetomidine, ketamine and opioids were used at commonly described dose ranges. $9,10,14,29,30$ In our study, body position during surgery did not significantly impact haemoglobin saturation since $\mathrm{SpO}_{2}$ levels did not vary between groups. Given that most cats were hypoxaemic at baseline, it is important to emphasise that the extend of the effects of body position or the effects of the surgery technique could have been masked. In this study, the cause of hypoxaemia was most commonly attributed to the combined respiratory depressant effects of alpha- 2 adrenergic agonists and ketamine in combination with butorphanol, that was most prominent before the beginning of surgery in the unstimulated animals. Overall, $\mathrm{SpO}_{2}$ values showed a trend during anaesthesia to improve with time, probably coinciding with a reduction of effective plasma levels of the drugs used; still, $\mathrm{SpO}_{2}$ values $<90 \%$ were observed at the end of surgery in $27 \pm 3 \%$ after the cats were repositioned into lateral recumbency for $5 \mathrm{~min}$. In general, the administration of supplemental oxygen, for example, by face mask could be a cheap and simple but effective solution to increase $\mathrm{SpO}_{2}$ values. As previously reported, ${ }^{9}$ supplementation of $100 \%$ oxygen typically resolves hypoxaemia maintaining $\mathrm{SpO}_{2}>95 \%$ in otherwise healthy animals and is therefore strongly recommended for cats anaesthetised with this drug combination.

While pulse oximetry has become an integral part of patient care in humans ${ }^{26}$ and veterinary medicine to detect potentially harmful situations, studies in both humans ${ }^{15,24}$ and animals ${ }^{19}$ have shown that readings at saturations less than $85 \%$ are not necessarily accurate. In children, a recent study found the Masimo Blue sensor using the SET technology had improved accuracy at saturations of $75-85 \%$ when compared to others (Nellcor N-600 with Max-I sensor). ${ }^{8}$ Nevertheless, when saturations fall below $85 \%$ cautious interpretation of pulse oximeter readings is warranted in both humans and cats, despite the development of newer technology. 8,19 In cats, the Masimo technology has been shown to provide a good accuracy when assessing $\mathrm{SpO}_{2}$ with these devices. ${ }^{16,17}$ Because the Masimo technology is currently not validated for use in cats, we performed a preliminary in-house testing of these devices in clinical patients with a variety of respiratory diseases and found accurate results with saturations down to $85 \%$ when directly compared to arterial blood gas analysis (RapidPoint 500 system - Siemens Healthcare AG, Freilgerstrasse 40, 8047 Zurich, Switzerland). 
However, this data was not statistically analysed and was limited to a small number of cases.

In our study, Trendelenburg and lateral position were associated with a shorter surgery time compared to dorsal position and this is in agreement with what has been previously reported. ${ }^{3}$ Theoretically, in our study this could have also been caused by the surgeon and not the technique itself. This seems unlikely as all surgeons involved were very experienced and have all castrated 1000 s of cats.

Regarding the IOP, the $70^{\circ}$ downward head tilt significantly increased IOP in our studied cats. In humans, the Trendelenburg position is also known to increase IOP ${ }^{18}$ although a short increase above $25 \mathrm{mmHg}$ in healthy patients lacking ocular or neurological diseases is generally self-limiting and not associated with detrimental consequences. ${ }^{21}$ In healthy cats, the IOP ranges between $10-25 \mathrm{mmHg} .{ }^{25}$ Similar to the effects of Trendelenburg in humans, it seems that no cat showed any obvious detrimental consequences from the increased IOP in the 24 postoperative hours in the present study (such as blepharospasmus, orbital tightening, excessive tearing, redness, etc). Trendelenburg has been shown to increase intracranial pressure (ICP) in human patients, but IOP is usually more affected than ICP. ${ }^{18}$ A correlation between increased IOP and ICP has been demonstrated in humans ${ }^{11}$ which could be also the case for cats. None of the enrolled cats in this study showed any visible neurological deficits possibly arising from an increase in ICP. However, in cats with ocular problems or whenever a short-lived increase in ICP could be harmful, it should be taken into consideration that the Trendelenburg position may worsen the pre-exiting conditions and should be avoided if possible.

The protocol MKB is used often for field spaying as it is relatively easy to administer and the volume to be injected is within limits that can be easily injected per cat. The drug dosages used are the ones commonly used by NetAP Switzerland. The dose of medetomidine used was lower than the registered dose (40 - $80 \mathrm{mg} / \mathrm{kg}$ i.m.) and the dose of ketamine higher than the registered one (5 - $7.5 \mathrm{mg} / \mathrm{kg}$ i.m.). ${ }^{22}$ However, the doses were within ranges that have been described to be suitable for spaying feral cats. ${ }^{9,29}$ In the present study approximately $18 \%$ of the total female cats required supplemental injection (15.7\% of all included cats). This may be due to either individual incomplete intramuscular delivery or individual variable excitement and sympathetic tone and thus response to anaesthetic drugs.

The present study has several limitations. First of all, anaesthetists were not blinded to the procedure as this was not possible. In order to reduce the significance of

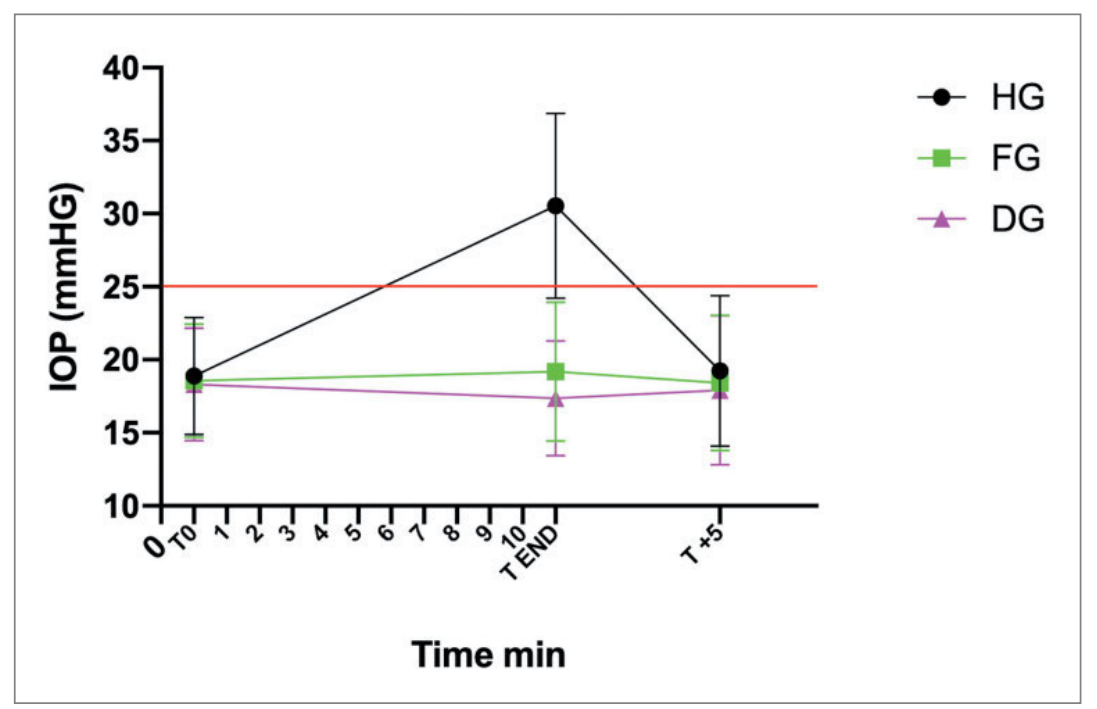

Figure 7: Intraocular pressure (IOP) (mean \pm SD) in the 3 different groups [HG (Head down/Trendelenburg Group), FG (Flank Group), DG (Dorsal Group)] before positioning for surgery, at the end of surgery and five minutes after the end of surgery back in lateral recumbency.

T0 = 1 Minute before positioning for surgery; $\mathbf{1 - 1 0}=10 \mathrm{~min}$ during surgery; $\mathbf{T}$-End = End of surgery; $\mathbf{T}+\mathbf{5}=5 \mathrm{~min}$ in lateral recumbency after end of the procedure.

this, each anaesthetist rotated on a daily basis between the three surgical tables where the measurements were taken. Arterial oxygenation was assessed indirectly by the means of $\mathrm{SpO}_{2}$ rather than directly via arterial blood gas analysis since this study was purely observational and performed in a field situation. It is possible, that drug-induced vasoconstriction might have influenced the accuracy of $\mathrm{SpO}_{2}$ readings although the SET technology from Masimo is, in theory, designed to be accurate in such conditions of low perfusion. ${ }^{27}$ This has been shown in cats receiving medetomidine, where the vasoconstriction due to activation of peripheral alpha2B-adrenoreceptors did not alter $\mathrm{SpO}_{2}$ reading based on the SET technology.17 In our study, sophisticated cardiopulmonary monitoring was not possible. Likewise, a sham group or an oxygen-supplementation control group which might have limited the conclusions of the study. The age of the animals could have influenced IOP since IOP reaches adult values by 3 months. ${ }^{1} \mathrm{Nev}-$ ertheless, all cats were considered older than 6 months based on dentition changes. Also, each cat served as their own control since a baseline measurement before surgical positioning was obtained. The long-term effects of the Trendelenburg technique on the IOP were not analysed in this study. Finally, the effects of Trendelenburg position on IOP in pre-existing ocular conditions were not evaluated because previous medical history was not available.

Proper detailed preoperative examination of animals was not possible and all cats brought to the clinic were anaesthetised. Only under anaesthesia some relevant 
Cats undergoing spay with medetomidine, ketamine and butorphanol develop arterial oxygen desaturation independent of surgical positioning and increased intraocular pressure in Trendelenburg position

D. Corona et al. pathologies (diaphragmatic hernia, pulmonary pathology) were discovered and the cats excluded, but it is possible that mild pathologies remained undiagnosed.

\section{Conclusions}

The results from 222 feral cats undergoing spay indicate that the incidence of hypoxia is high when using a MKB anaesthetic combination and not significantly variable among different surgical positions when no supplemental oxygen is administered. The Trendelenburg position induces a short-lived increase in IOP and possibly also ICP and should therefore be avoided in cases with pre-existing pathologies. Supplementation of oxygen in anaesthetised cats showing desaturation is recommended in any case.

\section{Acknowledgements}

We thank the students of the Vetsuisse Faculty University of Zurich, Switzerland, all the Staff of the Center of Hope Veterinary Hospital, Pitesca, Ilfov, Romanian and NetAP-Switzerland for their assistance during the preoperative period.

\section{Conflict of interest}

The authors declared no potential conflicts of interest with respect to the research, authorship, and/or publication of this article.

\section{Funding}

Drugs were sponsored by NetAP-Switzerland.

\section{Informed Consent}

This work involved the use of feral animals and therefore informed consent was not required. Only animals from a TNR-project were recruited in the study.

\section{Data statement}

The data are available to those interested by emailing to the corresponding author.

I gatti sottoposti a sterilizzazione con medetomidina, ketamina e butorfanolo sviluppano una desaturazione dell'ossigeno arterioso indipendentemente dalla posizione tenuta durante la chirurgia e un aumento della pressione intraoculare nella posizione di Trendelenburg

Questo studio ha osservato gli effetti di tre diverse posizioni chirurgiche sull'ossigenazione del sangue arterioso misurata in modo non invasivo tramite pulsossimetria $\left(\mathrm{SpO}_{2}\right)$ e sulla pressione intraoculare (IOP) nei gatti anestetizzati sottoposti a sterilizzazione. Un totale di 222 gatti selvatici femmine sono stati anestetizzati per un programma su larga scala trappola-neutro-ritorno con una combinazione intramuscolare di medetomidina $(0,03-0,05 \mathrm{mg} / \mathrm{kg})$, ketamina $(7-10 \mathrm{mg} / \mathrm{kg})$ e butorfanolo $(0,4 \mathrm{mg} / \mathrm{kg})$. I gatti sono stati randomizzati per essere sottoposti a sterilizzazione in posizione di Trendelenburg $\left(70^{\circ}\right.$ di inclinazione della testa verso il basso), laterale o dorsale. $\mathrm{La} \mathrm{SpO}_{2}$ e la frequenza del polso sono stati misurati al valore basale, prima del posizionamento chirurgico, dopo un minuto in posizione chirurgica e a intervalli di un minuto dopo l'incisione chirurgica. La pressione intraoculare è stata misurata prima del po- 
été mesurée avant le positionnement et à la fin de la chirurgie. À la fin de la chirurgie, toutes les chattes ont été placées en décubitus latéral gauche et tous les paramètres ont été réévalués après cinq minutes. Aucune différence significative entre les trois positions n'a été constatée concernant la $\mathrm{SpO}_{2}$, mais une augmentation au fil du temps a été observée. Au total, $52 \pm 10 \%$ (moyenne $\pm \mathrm{SD}$ ) des chattes étaient hypoxémiques $\left(\mathrm{SpO}_{2}<90 \%\right)$ au départ. $\mathrm{La} \mathrm{SpO}_{2}$ s'est améliorée avec le temps, mais $27 \pm 3 \%$ (moyenne $\pm \mathrm{SD}$ ) des chattes sont restées hypoxémiques à la fin de la chirurgie. La position de Trendelenburg a augmenté la PIO pendant la chirurgie (moyenne $31 \pm 6 \mathrm{mmHg}$, maximum individuel 48 $\mathrm{mmHg}$ ), contre $17 \pm 4 \mathrm{mmHg}$ en décubitus dorsal/latéral) mais s'est normalisée après 5 minutes en décubitus latéral. Toutes les chattes se sont bien remises de la chirurgie et ont été libérés dans les 24 heures suivant l'anesthésie.

Il a été démontré que la position chirurgicale pendant l'anesthésie n'avait aucune influence notable sur la $\mathrm{SpO}_{2}$ chez les chats ne recevant pas de supplémentation en oxygène, alors que la position de Trendelenburg entraînait une augmentation de la PIO. Une supplémentation en oxygène est recommandée avec ce protocole anesthésique, car une hypoxémie est fréquemment observée.

Mots clés: félin, chats sauvages, désaturation en oxygène de I'hémoglobine, hypoxémie, stérilisation. sizionamento e alla fine dell'intervento chirurgico. Alla fine dell'intervento, tutti i gatti sono stati posizionati sul decubito laterale sinistro e tutti i parametri sono stati rivalutati dopo cinque minuti. Non sono state riscontrate differenze significative tra le tre posizioni per quanto riguarda la $\mathrm{SpO}_{2}$, ma è stato osservato un aumento nel tempo. In totale, $52 \pm 10 \%$ (media \pm SD) gatti sono risultati ipossiemici $\left(\mathrm{SpO}_{2}<90 \%\right)$ al valore basale. $\mathrm{La} \mathrm{SpO}_{2}$ è migliorata nel tempo, ma $27 \pm 3 \%$ (media $\pm \mathrm{SD}$ ) gatti sono rimasti ipossiemici alla fine dell'intervento. La posizione di Trendelenburg ha determinato un aumento dell'IOP durante l'intervento chirurgico (una media di $31 \pm 6 \mathrm{mmHg}$, individuo max. $48 \mathrm{mmHg}$ risp. $17 \pm 4 \mathrm{mmHg}$ in posizione dorsale/laterale) ma si è normalizzata dopo 5 minuti in posizione laterale. Tutti i gatti si sono ripresi bene dall'intervento e sono stati rilasciati entro 24 ore dopo l'anestesia. La posizione chirurgica ha dimostrato di non avere un'influenza notevole sulla $\mathrm{SpO}_{2}$ durante l'anestesia nei gatti che non ricevono un'integrazione di ossigeno, mentre la posizione di Trendelenburg ha portato a un incremento della IOP. L'integrazione di ossigeno è raccomandata con questo protocollo anestetico, poiché l'ipossiemia è stata spesso rilevata.

Parole chiave: felini, gatti selvatici, desaturazione dell'ossigeno dell'emoglobina, ipossiemia, sterilizzazione.
Cats undergoing spay with medetomidine, ketamine and butorphanol develop arterial oxygen desaturation independent of surgical positioning and increased intraocular pressure in Trendelenburg position

D. Corona et al.

\section{References}

1 Adelman S, Shinsako D, Kiland JA, et al. The post-natal development of intraocular pressure in normal domestic cats ( Felis catus) and in feline congenital glaucoma. Experimental Eye Research. 2018;166:70-73. doi:10.1016/j.exer.2017.10.016

2 Arnemo JM, Ahlqvist R, Andersen F, et al. Rendez-Vous Risk of Capture-Related Mortality in Large Free-Ranging Mammals: Experiences from Scandinavia Terms of Use: Https://Bioone.Org/Terms-of-Use. Vol 2.; 2006. https://bioone.org/journals/Wildlife-Biology

${ }^{3}$ Asrat M, Melkamu S. Review on Ovariohysterectomy: Surgical approach, post-operative complications and their management in bitches. $30 \sim$ International Journal of Veterinary Sciences and Animal Husbandry. 2018;3(1): 30-35. www.veterinarypaper.com

${ }^{4}$ Borahay MA, Patel PR, Walsh TM, et al. Intraocular Pressure and Steep Trendelenburg During Minimally Invasive Gynecologic Surgery: Is There a Risk? Journal of MinimalIy Invasive Gynecology. 2013;20(6):819-824. doi:10.1016/j.jmig.2013.05.005

${ }^{5}$ Brodbelt DC, Pfeiffer DU, Young LE, Wood JLN. Risk factors for anaesthetic-related death in cats: results from the confidential enquiry into perioperative small animal fatalities (CEPSAF) †. British Journal of Anaesthesia. 2007;99(5):617-623. doi:10.1093/bja/aem229
${ }^{6}$ Fahy BG, Barnas GM, Nagle SE, Flowers JL, Njoku MJ, Agarwal M. Effects of Trendelenburg and Reverse Trendelenburg Postures on Lung and Chest Wall Mechanics. J Clin Anesth. 1996;8. doi:https://doi.org/10.1016/0952-8180(96)00017-7.

7 Halm MA. Trendelenburg Position: "Put to Bed" or Angled Toward Use in Your Unit? American Journal of Critical Care. 2012;21(6):449-452. doi:10.4037/ajcc2012657

8 Harris BU, Char DS, Feinstein JA, Verma A, Shiboski SC, Ramamoorthy C. Accuracy of Pulse Oximeters Intended for Hypoxemic Pediatric Patients. Pediatric Critical Care Medicine. 2016;17(4):315-320. doi:10.1097/PCC.0000000000000660

9 Harrison KA, Robertson SA, Levy JK, Isaza NM. Evaluation of medetomidine, ketamine and buprenorphine for neutering feral cats. Journal of Feline Medicine and Surgery. 2011;13(12):896-902. doi:10.1016/j.jfms.2011.06.010

10 Ko JC, Austin BR, Barletta M, Weil AB, Krimins RA, Payton $M E$. Evaluation of dexmedetomidine and ketamine in combination with various opioids as injectable anesthetic combinations for castration in cats. Journal of the American Veterinary Medical Association. 2011;239(11):14531462. doi:10.2460/javma.239.11.1453

11 Lashutka MK, Chandra A, Murray HN, Phillips GS, Hiestand BC. The relationship of intraocular pressure to intracranial pressure. Annals of Emergency Medicine. 2004;43(5):585-591.

doi:10.1016/j.annemergmed.2003.12.006 
Cats undergoing spay with medetomidine, ketamine and butorphanol develop arterial oxygen desaturation independent of surgical positioning and increased intraocular pressure in Trendelenburg position

D. Corona et al.
12 Lemke KA. Perioperative use of selective alpha -2 agonist and antagonists in small animals. Can Vet J. 2004;45:475 480.

13 Levy JK, Gale DW, Gale LA. Evaluation of the effect of a long-term trap-neuter-return and adoption program on a free-roaming cat population. Am Vet Med Assoc. 2003;222:42-46. doi:10.2460/javma.2003.222.42.

14 Lindsay S. Williams JKL SARAMCLACentonze. Use of the anesthetic combination of tiletamine, zolazepam, ketamine, and xylazine for neutering feral cats. JAVMA. $2002 ; 220$.

15 Louw A, Cracco C, Cerf C, et al. Accuracy of pulse oximetry in the intensive care unit. Intensive Care Medicine. 2001:27(10):1606-1613. doi:10.1007/s001340101064

${ }^{16}$ Mair A, Ferreira J, Ricco C, Nitzan M. Appraisal of the 'penumbra effect' using lingual pulse oximetry in anaesthetized dogs and cats. Veterinary Anaesthesia and Analgesia. 2020;47(2):177-182. doi:10.1016/j.vaa.2019.08.050

17 Mair A, Martinez-Taboada F, Nitzan M. Effect of lingual gauze swab placement on pulse oximeter readings in anaesthetised dogs and cats. Veterinary Record. 2017:180(2):49-49. doi:10.1136/vr.103861

18 Marshall-Goebel K, Mulder E, Bershad E, et al. Intracranial and Intraocular Pressure During Various Degrees of HeadDown Tilt. Aerospace Medicine and Human Performance. 2017;88(1):10-16. doi:10.3357/AMHP.4653.2017

19 Matthews NS, Hartke S, Allen JC. An evaluation of pulse oximeters in dogs, cats and horses. Veterinary Anaesthesia and Analgesia. 2003;30(1):3-14 doi:10.1046/j.1467-2995.2003.00121.x

20 McLamb E. Real Ecology, Born in the streets: the global impact of feral cats. Ecology Global Network. 2013;27.

21 Nagdeve NG, Yaddanapudi S, Pandav SS. The Effect of Different Doses of Ketamine on Intraocular Pressure in Anesthetized Children. Journal of Pediatric Ophthalmology and Strabismus. 2006;43(4):219-223. doi:10.3928/01913913-20060701-03

22 Ramsey I. BSAVA Small Animal Formulary-Part A: Canine and Feline,. (Ramsey I, ed.). British Small Animal Veterinary Association; 2017.

${ }^{23}$ Robertson SA TP LBDM. Changes in thermal threshold response in eight cats after administration of buprenorphine, butorphanol and morphine. Vet Rec. 2003;153:462465 .

${ }^{24}$ Ross PA, Newth CJL, Khemani RG. Accuracy of Pulse Oximetry in Children. Pediatrics. 2014;133(1):22-29. doi:10.1542/peds.2013-1760

${ }^{25}$ Rusanen E, Florin M, Hässig M, Spiess BM. Evaluation of a rebound tonometer (Tonovet ${ }^{\circledR}$ ) in clinically normal cat eyes. Veterinary Ophthalmology. 2010;13(1):31-36. doi:10.1111/j.1463-5224.2009.00752.x

${ }^{26}$ Severinghaus JW. Takuo Aoyagi: Discovery of Pulse Oximetry. Anesthesia \& Analgesia. 2007;105(On Line Suppl.):S1-S4. doi:10.1213/01.ane.0000269514.31660.09

27 Shah N, Ragaswamy HB, Govindugari K, Estanol L. Performance of three new-generation pulse oximeters during motion and low perfusion in volunteers. Journal of Clinical Anesthesia. 2012;24(5):385-391. doi:10.1016/j.jclinane.2011.10.012

28 Team RC. R: a language and environment for statistica computing, version 3.0. 2. R Foundation for Statistical Computing. Published online 2019.
${ }^{29}$ Verstegen J, Fargetton X, Donnay I, Ectors F. An evaluation of medetomidine/ketamine and other drug combinations for anaesthesia in cats. Veterinary Record. 1991;128(2):32-35. doi:10.1136/vr.128.2.32

${ }^{30}$ Wiese A, Muir W. Anaesthetic and cardiopulmonary effects of intramuscular morphine, medetomidine and ketamine administered to telemetered cats. Journal of Feline Medicine \& Surgery. 2007;9(2):150-156. doi:10.1016/j.jfms.2006.11.002

${ }^{31}$ Wood S. SF. Package 'gamm4. Am Stat. 2017;45.

\section{Corresponding author}

Daniele Corona

Department of Clinical Diagnostics and Services, Section of Anaesthesiology, Vetsuisse Faculty University of Zurich Winterthurerstrasse 258c

8057 Zurich, Switzerland

Phone number: 0041796503259

E-Mail:daniele.corona@uzh.ch 